\title{
THE ROLE OF TRUST DIMENSION UNDER CONDITIONS OF NETWORK ORGANISATIONS' COOPERATION
}

\author{
Janusz Kroik ${ }^{\mathrm{a}}$, Adam Świda \\ ${ }^{\mathrm{a}, \mathrm{b}}$ Wroclaw University of Technology, \\ Department of Computer Science and Management, Wroclaw, Poland \\ ${ }^{a}$ e-mail: janusz.kroik@pwr.edu.pl \\ be-mail: adam.swida@pwr.edu.pl
} $J P M *$ IOURNAL OF POSITIVE MANAGEMENT

Vol. 7, No. 4, 2016, pp. 71-80 (C) Copyright by Wydawnictwo Naukowe Uniwersytetu Mikołaja Kopernika
ISSN 2083-103X

http://dx.doi.org/ 10.12775/JPM.2016.024

\begin{abstract}
Purpose: Main purpose of the article is creating the categories and premises of trust, shaped through different forms of cooperation undertaken between companies in a selected economic group in Poland, and then - on the basis of opinions of managers/owners - assess the significance of the behavioural dimension of trust for conditions prevailing in this group.

Methodology/approach: The basis for conducting an analysis of the problem of trust involved interviews conducted with the owners and/or key managers of 14 production companies. The obtained opinions on cooperation pointed out, on the one hand, distrust and rivalry, but also continuous cooperation and joint investments. Interviews were conducted with 6 small-sized companies, as well as 8 larger. All companies had long-term experience in operation within a group - at least 10 years of participation.
\end{abstract}

Findings: The adopted methodology and manner of distinguishing dimensions of trust, for which a numeric evaluation of relations was introduced, captured the general framework of direct and indirect relations and condition of trust.

Implications: The process of creating cooperation clusters among firms (especially in selected industrial sectors) will meet the problem of trust. The methods of measuring the trust level should be popularized and discussed.

Originality/value of the paper: Empirical researches results have special value for recognizing contemporary and future managerial challenges. Identification these important challenges (like problem of multi organizational trust), could help in preparing firm's cooperation and competition activities.

Keywords: cooperation, trust type, group of enterprises, reviews, managers

Paper type: Research paper 


\section{Introduction}

The issues of cooperation between companies are one of the key problems raised in the management sciences. Recently, we can observe a strong emphasis on the networking characteristics, which result from development of cooperation and the growing interest of management researchers in the issues of inter-organisational networks (Czakon, 2012; Dytczak and Ginda, 2013). In the discipline of management sciences, networking refers both to strategic management, which covers examination of clusters, innovation systems, business partnership, and franchise networks, but also to delivery networks and, finally, to management of intangible resources in the form of knowledge and social capital. On the other hand, it is emphasised that an analysis of the cooperation networking phenomenon may demonstrate a positive impact of networks, strengthening of trust and cooperation within the network (Klimas, 2016). The role of trust in network systems is emphasised in various contexts. This applies to companies (Sankowska, 2011) and typical network systems. In the latter, emphasis is put on the fact that relations in inter-organisational networks are linked with the existence of trust between the network participants (Christidu-Budnik, 2011). Some authors indicate the need to distinguish trust from credibility, stressing that the evidence of credibility is the first to appear, followed by trust. Such evidence may include experiences of cooperation between companies and its forms. In general, intuition and organisational practice suggest that distrust is easily built, since it only requires limited knowledge, whereas trust needs a broader examination of knowledge about the motives (Machnikowski, 2010).

Taken from the article title dimension of trust relates to words like: type, kind, base, source etc. It is used at situation of measuring trust researches (Levin and Cross, 2004) [1]. Authors of the article emphasize the fact of estimating a mutual relations different trust types, especially integrated trust. Integrated trust is popular in some research approaches (Paul and McDaniel, 2004), (Sankowska, 2015) [2].

Trust used in the empirical part of the article is examined in three dimensions: first - cognitive, (CD) in which full knowledge is an alternative to trust. Moderate knowledge is the basis for generating trust towards the risk occurring due to incomplete level of knowledge.

The second dimension of trust is affective (AD). It is based on a positive emotional bond between the participants in the relations, built through prior familiarity and experiences created due to this familiarity. This dimension plays a special role in creation of inter-organisational cooperation networks, especially informal ones. The third dimension - behavioural (BD), results from long-term experience of cooperation, for which the source of uncertainty is reduced, but it is possible to enforce the expectations we have in the trusted person, which have not been met, at any moment. Appeal institutions (courts) are used for this purpose. 
Inter-organisational network, as mentioned above, is associated with trust and is the condition for its existence. For example, according to the OECD's definition, network is a special form of relations between entities, based on interdependencies, cooperation and trust (Brodzicki and Szultka, 2002). A business network is a set of long-term formal and informal, direct and indirect relations between two or more entities (Ratajczak-Mrozek, 2009). To sum up, the essence and premise for cooperation between companies is development, understood as effective adaptation to the changing environment. Thus, the arising cooperation bonds are created on the basis of diverse resources of particular partners, and trust should be an element of these resources or a premise to use them.

The purpose of the article is creating the categories and premises of trust, shaped through different forms of cooperation undertaken between companies in a selected economic group in Poland, and then - on the basis of opinions of managers/owners - assess the significance of the behavioural dimension of trust for conditions prevailing in this group.

It seems that the behavioural dimension should have the greatest importance in shaping trust in the examined economic group. The premise to formulate this presumption is the long period of incubation and development of the group, whose beginnings reach the early 1990s. This period should mark the occurrence of conditions for introducing the clear premises for coopetition (syncretic activity of competition and cooperation) in the practice of companies.

The problem could be regarded by two type issues: sector and corporative. The proposition of four areas matrix of coopetition (polish term: kooperencji) is suitable method for analysing that (Cygler, 2009).

The informational basis for assessing the context of trust are the results of 14 interviews conducted in 2016, concerning the forms and types of cooperation between enterprises operating in high local concentration of companies from the furniture industry.

Types and activities characterising cooperation were divided into three groups adequate to the symptoms of trust, according to the three aforementioned dimensions. The proper intensity scale of this cooperation (and trust) was applied, and then, using the DEMETEL method, the situation was diagnosed and conclusions were drawn.

\section{Inter-organisational bonds under conditions of network cooperation}

It is assumed that long-term maintenance of a relative balance in the coopetition phenomenon may be the source of trust in the case of informal cooperation networks. In the case of formal networks, it is assumed that coopetition limits or even eliminates trust (Christidu-Budnik, 2011). 
THE ROLE OF TRUST DIMENSION

Janusz Kroik Adam Świda

Table 1. Factors affecting the three cooperation formulas of participants in the economic group

Source: on the basis of (Góra, 2008).

74
On the other hand, researchers argue that without proper focus on internal communication and dialogue within the economic group, such an arrangement does not constitute a local production system and is not a social system (Fic et al., 2016).

A model cluster of network cooperation is characterised by:

1) Intense focus on improvement of industrial processes and final products, focus on innovations and technology development. These networks, consisting of various entities, seek common ideas and visions, therefore building social capital and additional value added;

2) Obtaining additional benefits from functioning within the group by entities manufacturing similar and complementary products. They use external effects towards suppliers and other stakeholders. The internal effects include increase in skills, collective diffusion of knowledge and innovation, development of institutions strengthening the local economic development within formal and informal bonds.

The perception of the aforementioned effects of network cooperation affects trust in the abovementioned three dimensions, including the behavioural dimension, based on the conditional option of verifiability of this trust by legal means.

The essence of networking, as a relational quality of description of the economic reality, is the fact that it concerns behavioural norms and the necessary trust rather than the structures necessary for efficient inter-organisational cooperation (Czakon, 2014). An important context for the company's continued participation in the cluster is estimation of risk when entering inter-organisational relations. In the course of the subsequent phases (stages), trust becomes a key factor integrating the willingness to cooperate (Grudzewski et al., 2008).

Studies on the groups indicate three cooperation formulas: common business initiatives, entering into psychological contracts, and execution of social contracts. These formulas are shown in Table 1.

\begin{tabular}{ll}
\hline Formulas for cooperation in the group & Factors favourable to a given formula \\
\hline Joint business actions & $\begin{array}{l}\text { Strategic convergence, participation of direct and } \\
\text { indirect contacts in the group participants' past }\end{array}$ \\
\hline Entering into psychological contracts & $\begin{array}{l}\text { Perception of convergence of expectations, diversity } \\
\text { of social structure of the group participants }\end{array}$ \\
\hline Implementation of social contracts & $\begin{array}{l}\text { Degree of mutual trust, exposure of social position } \\
\text { of the group participants }\end{array}$ \\
\hline
\end{tabular}

The list presented in Table 1 suggests a certain gradual nature and distinctness of the sources of emerging trust. However, they cannot constitute a basis for indicating that we are dealing with three dimensions of trust adequate to a given formula of cooperation. The aforementioned phenomenon 
of coopetition (cooperation and competition), which involves limitation of trust when it has a formalised form, means that its informal aspect of the cooperating entities is based on trust. This general comment represents the benefits of adopting the coopetition form, indicated in the literature. These include, among others:

- Learning about the organisation, as a result of sharing knowledge, knowhow, as well as skills and experience;

- Acquisition of access to modern technologies, and consequently entering into new markets;

- Building better customer relationships by offering broader range of products, which would be impossible to achieve in the case of individual activities;

- More effective competition with rivals who are not business partners, as a result of creation of a greater range of goods and services offered on the market (Czakon, 2013).

The need to gain knowledge is certainly the key premise for coopetition, however, at the same time, it may be a barrier - in such a case, organisations are highly reluctant to share their individual knowledge. The phenomenon of coopetition applies to many sectors of the economy, especially to technologically advanced sectors, however, it may be also observed in the sector of small and medium enterprises, as well as in business networks and clusters (Romaniuk, 2012).

\section{Types of cooperation of companies as premises for determination of the aspect (dimension) of trust}

The basis for conducting an analysis of the problem of trust involved interviews conducted with the owners and/or key managers of 14 production companies. The full interview can be found in (Dziergwa, 2016). The obtained opinions on cooperation pointed out, on the one hand, distrust and rivalry, but also continuous cooperation and joint investments. Interviews were conducted with 6 small-sized companies ( 2 employing up to 10 employees, and 4 - up to 50), as well as 8 larger companies ( 4 with more than 50 people, and 2 with more than 100 people). All companies had long-term experience in operation within a group - at least 10 years of participation.

Analysis of the content of the interviews allowed for identifying three contexts and sources of building trust. In the opinion of the authors, they correspond to the three abovementioned dimensions. Thus, it has been assumed that:

1) The cognitive dimension of trust (CD) is affected by:

duration of acquaintance, number of contacts, scope of cooperation, awareness of conveniences, take-over of patterns from others.

2) In the affective aspect of trust (AD), the following factors were indicated:

Figure 1. Four leadership strategies that enable positive deviance (Cameron,

2008)
OF TRUST DIMENSION

Janusz Kroik Adam Świda 
Janusz Kroik Adam Świda

Table 2. Number of experts' indications concerning the mutual impact between cooperation factors qualified into $\mathrm{CD}, \mathrm{AD}, \mathrm{BD}$, according to the scale $[0,1,3]$

Source: prepared by the authors. joint achievement of benefits under: access, negotiations, deliveries, fairstype events, exhibitions, family relations, local social projects, awareness of reliability of partners.

3) Trust in the behavioural dimension (BD) resulted from the following situations:

operational cooperation, repeatability of contracts, infrastructure sharing, joint procurements, imitation of ideas and processes.

It turned out that the diagnosed factors are interconnected and, according to the respondents, have different causative strength. The above assumptions were used for analysis of mutual interactions between particular cooperation activities among companies.

Therefore, the analysis of trust resulting from cooperation of companies within a group used the DEMATEL method, known also from its application in the field of economics and management (Dytczak and Ginda, 2013).

In accordance with the DEMATEL method's assumptions, it has been assumed that the roles of experts are assumed by the persons giving the interview $(K=14)$. The classic approach to the method assumes that the experts' opinions are weighed equally, i.e. using arithmetic mean. The interviews prevented precise assessment of the impact of particular cooperation factors, since the opinions stated that they have "no impact", "small impact" or "significant impact". It was substantively reflected in the adopted measurement scale. Apart from the state expressing lack of impact $-\mathrm{N}=0$, two other states were distinguished, symbolising: small impact $(\mathrm{N}=1)$ and (with a number skipped) large impact $(\mathrm{N}=3)$.

Table 2 presents the experts' opinions on these three states [number $\mathrm{N}=0$, number $\mathrm{N}=1$, number $\mathrm{N}=3$ ] of mutual interaction between cooperation factors qualified into the three dimensions of trust.

\begin{tabular}{|c|c|c|c|}
\hline & CD & AD & BD \\
\hline $\mathrm{CD}$ & & {$[6,6,2]$} & {$[1,9,4]$} \\
\hline $\mathrm{AD}$ & {$[2,7,5]$} & ----- & {$[1,8,5]$} \\
\hline $\mathrm{BD}$ & {$[4,9,1]$} & {$[4,8,2]$} & \\
\hline
\end{tabular}

According to the DEMATEL methodology, the basis for the analysis is the direct impact matrix $\mathbf{X}^{*}$ and its normalised form $\mathbf{X}$. Table 3 presents both matrixes. The additional column contains single-row sums necessary to determine the normalised - according to the maximum value of the single-row sum - form of the direct impact matrix $\mathbf{X}$. 


\begin{tabular}{l|lll|l}
\hline $\begin{array}{c}\mathrm{x}_{\mathrm{ij}}{ }^{*} \\
{\left[\mathrm{x}_{\mathrm{ij}}\right]}\end{array}$ & CD & AD & BD & \multicolumn{2}{c}{ single-row sum } \\
\hline $\mathrm{CD}$ & 0 & $\begin{array}{l}0.86 \\
{[0.27]}\end{array}$ & $\begin{array}{l}1.5 \\
{[0.467]}\end{array}$ & 2.36 \\
\hline $\mathrm{AD}$ & $\begin{array}{l}1.57 \\
{[0.489]}\end{array}$ & 0 & $\begin{array}{l}1.64 \\
{[0.511]}\end{array}$ & $\begin{array}{l}3.21 \\
(\max .)\end{array}$ \\
\hline $\mathrm{BD}$ & $\begin{array}{l}0.86 \\
{[0.268]}\end{array}$ & $\begin{array}{l}1.0 \\
{[0.312]}\end{array}$ & 0 & 1.86 \\
\hline
\end{tabular}

Data included in the matrix $\mathbf{X}$ allow for estimating the total, namely the direct and indirect, impact of the three dimensions of trust evaluated through the adopted system of cooperation forms of the 14 examined companies (according to the DEMATEL method, these are evaluations made by $\mathrm{k}=14$ experts) operating within an economic group.

\section{Characterisation of the position and role of behavioural trust}

In order to obtain an answer to the question set out in the introduction, concerning behavioural trust, we need to estimate the total impact of the recorded relations. As mentioned before, data from the normalised matrix $\mathbf{X}$ make this possible, after this matrix has been properly transformed. The formula of this transformation, resulting in matrix $\mathbf{T}$, is obtained according to a well-known mathematical formula $\mathbf{T}=\mathbf{X}^{*}(\mathbf{I}-\mathbf{X})-1$ (Dytczak and Ginda, 2013). Table 4 below is a synthetic list of the calculated matrix $\mathbf{T}$. It includes both $t_{\mathrm{ij}}$ elements of matrix $\mathbf{T}$, as well as ratios of sums $t_{i j}$ according to columns and rows (accordingly, $d_{i}$ and $r_{j}$ ), used to determine the position of a given element (gross impact) and the type of its relations (net impact). Both characteristics are shown in two columns - position $\left(d_{i}+r_{j}\right.$, for $\left.i=j\right)$ and cause-and-effect relation $\left(\mathrm{d}_{\mathrm{i}}-\mathrm{r}_{\mathrm{j}}\right.$, for $\left.\mathrm{i}=\mathrm{j}\right)$.

\begin{tabular}{|c|c|c|c|c|c|c|}
\hline $\mathbf{t}_{\mathrm{ij}}$ & CD & AD & BD & $\mathbf{d}_{\mathrm{i}}$ & $\begin{array}{l}\mathbf{D}+\mathbf{R} \\
\left(\mathbf{d}_{\mathrm{i}}+\mathbf{r}_{\mathrm{j}}\right) \\
\text { for } \mathbf{i}=\mathbf{j}\end{array}$ & $\begin{array}{l}D-R \\
\left(d_{i}-r_{j}\right) \\
\text { for } i=j\end{array}$ \\
\hline $\mathrm{CD}$ & 0.7690 & 0.8748 & 1.2731 & 2.9169 & 5.8882 & -0.0544 \\
\hline $\mathrm{AD}$ & 1.3173 & 0.8411 & 1.5560 & 3.7144 & 6.2392 & 1.1896 \\
\hline BD & 0.8850 & 0.8089 & 0.8266 & 2.5205 & 6.1762 & -1.1507 \\
\hline$r_{j}$ & 2.9713 & 2.5248 & 3.6557 & & & \\
\hline
\end{tabular}

Table 3. Direct impact matrixes $\mathbf{X}^{*}$ and their normalised forms $\mathbf{X}$ (numbers in square brackets [ ]) according to the maximum value of the single-row sum

Source: prepared by the authors.

Table 4. Assessment of the total impact of three dimensions of trust, their position $(\mathrm{D}+\mathrm{R})$ and relation type (D-R) in the opinion of 14 experts - managers

of production companies from a selected economic group from the furniture sector

Source: prepared by the authors. 
The results presented in Table 4 show the diversity of dimensions of trust formed in such a way. Trust with a behavioural basis BD has a clearly consequential nature, since the $\mathrm{D}-\mathrm{R}$ ratio is negative $(\mathrm{d}-\mathrm{r}=-1.1507)$. This means that undertaking operational cooperation is rather caused by other aspects of building trust: affective and cognitive. Actual cooperation is reached on the basis of getting to know each other better, participation in various business-related projects or local initiatives. Thus, activities within the emotional dimension (AD) clearly have a clear causal nature (positive R-D) $(\mathrm{d}-\mathrm{r}=1.1896)$. The position $(\mathrm{D}+\mathrm{R})$ of two trust dimensions $\mathrm{BD}$ and $\mathrm{AD}$ is comparable (6.176 and 6.239), which means a relatively comparable significance (not necessarily high) in the shaped phenomenon of trust generated by cooperation.

The interviews with managers/owners indicated high caution when establishing deeper cooperation between production companies, with the reasons for such a state resulting from more intense competition and searching for partners in the company's own string of the value chain. However, the emerging cooperation and joint investments do not have a strategic nature. There is a risk and caution when sharing knowledge, especially skills, although imitation is noticeable and in its own way generates the aspect of trust. As for the aforementioned coopetition, it is present in a group, but to a limited extent. It is evidenced by the low position of the $\mathrm{CD}$ dimension. However, the operational cooperation undertaken with other producers incorporates informal aspects, and so it is also based on the premises of trust towards partners. Such a state of competition and cooperation is also impacted by the dominating position of two suppliers of faux wood boards, who dictate the general terms and conditions of access and prices.

\section{Conclusions}

The general conclusion resulting from the analysis of cooperation between companies in a selected economic group is that a potentially strong source of trust may be built under BD, i.e. operational cooperation, sharing of infrastructure and joint procurements, resulting in a scale effect. These actions turned out to be net actions, an impact for other signs of cooperation, closer to the CD and ED dimensions. How cooperation within BD is reflected in general trust depends on practical experiences, since its level was not deemed to be significant. Managers clearly indicated distrust in transfer of knowledge, particularly skills, in undertaking possible cooperation.

The difficulties in raising trust between territorially concentrated sector entities are proven by findings of the comparative study for the wood and furniture industry of the Podlaskie Voivodship, carried out by A. Wasiluk. Among the examined sample of $\mathrm{N}=73$ companies, $72 \%$ of which operating on the market for more than 10 years, the level of inter-organisational trust amounted to 3.25, whereas the level of cooperation -2.68 . The study used a $1-6$ the scale, where: 1 
meant lack of trust/cooperation. Interpretation of the results indicates quite a low level of trust towards competitors and a residual level of cooperation (Wasiluk, 2013).

Thus, it was confirmed that the phenomenon of coopetition is a business formula difficult to execute, even within economic groups with stable characteristics, represented by the examined cluster of the furniture sector. Perhaps a very big number of companies gathered in this group on a small area of one county (about a thousand companies) is also an additional barrier for developing deeper trust in economic relations of the entities located therein. Assessment of coopetition (kooperencji) at furniture cluster depends on sector issues. The phase of sector life cycle (mature) and character of cooperation (matrix area number 4) suggested unstable relations of cooperative cooperation (Cygler, 2009). More detailed assessment of this issue needs additional empirical researches.

The adopted methodology and manner of distinguishing dimensions of trust, for which a numeric evaluation of relations was introduced, obviously has many subjective features, e.g. the very selection of the cooperation categories for the dimensions of trust, or the adopted measurement scale of intensity of relations. However, it seems that it captured the general framework of direct and indirect relations, forming the complex phenomenon and condition of trust.

\section{Notes}

[1] The word dimension is used in measure: a competence-based trust and benevolence-based trust, at process of knowledge transfer among enterprises.

[2] In that approach - integrated trust consist of: calculation, knowledge, identification.

\section{References}

Brodzicki, T., Szultka, S. (2002), "Koncepcja klastrów a konkurencyjność przedsiębiorstw”, Organizacja i Kierowanie, No. 4, pp. 45-60.

Christidu-Budnik, A. (2011), "Zaufanie i wiarygodność w sieciach międzyorganizacyjnych", Prace Naukowe Uniwersytetu Ekonomicznego we Wrocławiu, No. 217, pp. 63-76.

Cygler, J. (2009), Kooperencja przedsiębiorstw. Czynniki sektorowe i korporacyjne, Wydawnictwo Szkoła Główna Handlowa w Warszawie, Warszawa.

Czakon, W. (2012), Sieci w zarządzaniu strategicznym, Wolters Kluwer, Warszawa.

Czakon, W. (2013), "Strategia koopetycji w rozwoju organizacji”, Zeszyty Naukowe Politechniki Łódzkiej, No. 1147, pp. 127-134.

Czakon, W. (2014), "O ograniczeniach strukturalizmu w badaniach sieci międzyorganizacyjnych”, Organizacja i Kierowanie, No. 1A, pp. 27-35.

Dytczak, M., Ginda, G. (2013), "Miejsce metody DEMATEL w rozwiązywaniu złożonych zadań decyzyjnych”, Zeszyty Naukowe Wyższej Szkoły Bankowej we Wrocławiu, T.15, No. 5, pp. 631-644.

Dziergwa, M. (2016), “Współpraca przedsiębiorstw w klastrach branżowych na przykładzie 
kępińskiego klastra meblowego", master thesis, Wydział Informatyki i Zarządzania Politechniki Wrocławskiej, Wrocław.

Fic, M., Fic, D., Piątyszek-Pych, A. (2016), "Klastry jako przykład sieci współpracy przedsiębiorstw”, in: Malara, Z. (Ed.), Oblicza innowacji w gospodarce i społeczeństwie, Oficyna Wydawnicza Politechniki Wrocławskiej, Wrocław, pp. 56-57.

Góra, J. (2008), Dynamika klastra - zarys teorii i metodyka badań, Wydawnictwo Wyższej Szkoły Handlowej, Wrocław.

Grudzewski, W. M., Hejduk, I., Sankowska, A. (2008), "Rola zarządzania zaufaniem we współczesnej gospodarce", E-mentor, Vol. 4 No. 26.

Klimas, P. (2016), "Analiza sieciowa i zmienne strukturalne w badaniach sieci dostaw", Organizacja i Kierowanie, No. 3, pp. 53-66.

Levin, D., Cross, R. (2004), "The strength of weak ties you can trust: the mediating role of trust in effective knowledge transfer", Management Science, Vol. 50 No. 11, pp. 1477-1490. DOI: http://dx.doi.org/10.1287/mnsc.1030.0136

Machnikowski, P. (2010), Prawne instrumenty ochrony zaufania przy zawieraniu umowy, Wydawnictwo Uniwersytetu Wrocławskiego, Wrocław.

Paul, D. L., McDaniel, J. R. R. (2004), "A field study of the effect of interpersonal trust on virtual collaborative relationship performance", MIS Quarterly, Vol. 28 No. 2, pp. 183-227.

Ratajczak-Mrozek, M. (2009), "Sieci biznesowe na tle innych koncepcji kooperacji przedsiębiorstw", Gospodarka Narodowa, No. 7-8, pp. 79-91.

Romaniuk, K. (2012), "Koopetycja przedsiębiorstw - nowa perspektywa”, Wspótczesne Zarządzanie, No. 4, pp. 65-72.

Sankowska, A. (2011), Wpływ zaufania na zarządzanie przedsiębiorstwem, Difin, Warszawa.

Sankowska, A. (2015), "Zaufanie w łańcuchu dostaw -determinanty, typy i konsekwencje", Studia Ekonomiczne. Zeszyty Naukowe Uniwersytetu Ekonomicznego w Katowicach, No. 217, pp. 19-30.

Wasiluk, A. (2013), "Zaufanie i współpraca pomiędzy przedsiębiorstwami w perspektywie budowy i rozwoju struktur klastrowych", Economics and Management, Vol. 5 No. 4 , pp. 49-66. 